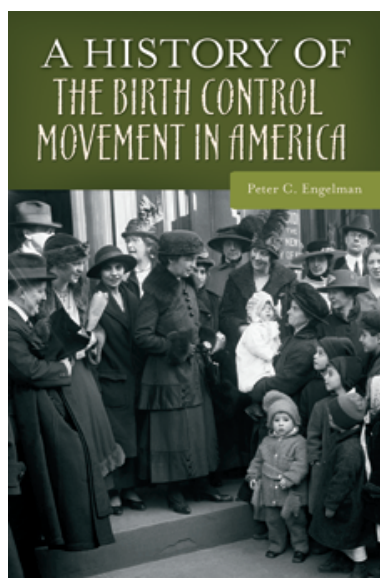

\title{
A history of the birth control movement in America
}

\author{
Peter C. Engelman \\ Praeger. Santa Barbara, California, USA. 2011. \\ 248 pp. \$44.95. ISBN: 978-0-313-36509-6 (hardcover). \\ Reviewed by John K. Amory \\ University of Washington School of Medicine, Seattle, Washington, USA. \\ E-mail: jamory@u.washington.edu
}

he struggle for women's rights gets less attention today than other civil rights struggles of the 20th century. However, the history of the fight for women's rights created the model for societal change that was followed by the later movements and has much to teach us about how to create a more equitable society. One crucial aspect was the effort to legalize contraception in the United States between 1914 and 1940. This period is the subject of a new book entitled A History of the Birth Control Movement in America, written for a general audience by Peter C. Engelman, the associate editor of the Margaret Sanger Papers Project at New York University.

After a brief summary of contraceptive practices in the 19th century, Engelman introduces the reader to the villain of the history, the notorious "vice crusader" Anthony Comstock, who lobbied Congress and won passage of the Federal Comstock Act. The legislation suppressed "the circulation of obscene literature and articles of immoral use," including contraceptives. He spent the 40 remaining years of his life arresting over 3,000 individuals and confiscating over 160 tons of materials he deemed to be obscene. In large part due to his efforts, prior to 1915 , contraception was hard to obtain and rarely discussed in public.

Enter Margaret Sanger, the sixth of 11 children born to a stone cutter and his Catholic wife in upstate New York. Sanger would later bluntly state that her mother's death at age 50 was from "having too many children and working herself to death." After marrying and having three children of her own, Sanger became interested in radical politics and moved to Manhattan.
Like the famous socialist Emma Goldman, Sanger worked as an obstetrical nurse in the tenement districts of the lower East Side. There, she was exposed to a level of squalor and suffering she had not previously witnessed. Women begged for relief from childbearing and resorted to home remedies such as turpentine or knitting needles in efforts to induce abortions. After witnessing several women dying from septicemia following unsterile abortions, Sanger decided to educate herself in methods of reproductive control. She wrote, "I resolved that women should have knowledge of contraception. They have every right to know about their own bodies.” From 1914 on, Sanger embarked on a lifelong quest to provide women with information about methods of contraception. Starting first from a self-published newspaper and graduating to a national lecture circuit over the next dozen years, she became the most famous advocate for improving access to contraceptives, coining the term birth control in the process. Her actions brought her in frequent contact with Anthony Comstock and the police, who arrested her no fewer than eight times. Inevitably, these incarcerations only increased her notoriety and served to bring the issue of birth control to the attention of the public, from whom she increasingly gained support.

By the 1920s, Sanger had deradicalized her image and began seeking alliances with the medical and scientific community. This helped with her legislative efforts to overturn the Comstock laws and led to a broader understanding of the efficacy of the contraceptive methods then available, mainly diaphragms, vaginal suppositories, and douching techniques. This "medical- ization" of birth control eventually led to a clinic system, the precursor of the Planned Parenthood clinics, which today provide much of the access to contraception to women in the US. There is a lot of wonderful history in this book, including the twists and turns of several important legal cases, which remarkably continued up until 1972, when the Supreme Court finally legalized all forms of contraception for all individuals.

Drawing on his access to Sanger's letters and the often heartbreaking pleas for her help from desperate women that Sanger received, Engelman is able to paint a powerful picture of the role of birth control in the lives of women during this era. If the book has a flaw, it is that it leaves the reader wanting to know more about Sanger and her remarkable impact on the history of contraception. For example, Sanger's crucial role in finding the funding necessary for the development of the oral contraceptive is glossed over in a few paragraphs near the end of the narrative. Fortunately, for the interested reader, a wonderful full biography of Sanger (1) and additional perspectives on the role of birth control in America (2) are still in print. In summary, Engelman's new work provides a brief and well-written introduction to this fascinating and overlooked American social reform movement and its complicated but passionate hero, Margaret Sanger.

1. Chesler E. Margaret Sanger and the birth control movement in America. New York, New York, USA: Doubleday; 2007

2. Tone A. Devices and desires: a bistory of contraceptives in America. New York, New York, USA: Hill and Wang; 2001. 